\title{
КОМПЛЕКСНА ОЦІНКА ОСНОВНИХ СКЛАДОВИХ ЗДОРОВОГО СПОСОБУ ЖИТТЯ У ВІЙСЬКОВОСЛУЖБОВЦІВ ВІЙСЬКОВО-МОРСЬКИХ СИЛ ЗБРОЙНИХ СИЛ УКРАЇНИ З ХВОРОБАМИ СИСТЕМИ КРОВООБІГУ ТА ХРОНІЧНОЮ ТЕРАПЕВТИЧНОЮ ПАТОЛОГІЄЮ
}

\author{
І.К. Середа ${ }^{1}$, Ж.М. Олещенко²
}

\author{
1 Українська військово медична академія, м. Київ, Україна \\ ${ }^{2}$ Командування Морської піхоти Військово-Морських Сил ЗС України, м. Миколаӥв, Україна
}

\begin{abstract}
Мета роботи - комплексно оцінити медико-соціальні аспекти основних складових здорового способу життя у військовослужбовців ВМС ЗС України з хворобами системи кровообігу та хронічною терапевтичною патологією для виявлення найвагоміших ризиків і розробці на цій основі сфокусованих заходів щодо їх зменшення.

Матеріали та методи. Медико-соціальні аспекти основних складових здорового способу життя (ЗСЖ) у військовослужбовців ВМС ЗС України були проаналізовані за результатами соціологічного опитування з застосуванням спеціально розробленої анкети. Анкета включала 43 питання, що були зведені в інформаційні блоки: загальні відомості, поінформованість щодо ЗСЖ, поширеність та причини шкідливих звичок, аналіз способу життя (особливостей харчування, бізичної активності, режиму праці та відпочинку), самооцінка стану здоров'я та таблищю щодо визначення задоволеності різними сторонами життя за наступними критеріями: умови праці та перспективи службового росту, забезпеченість житлом та побутові умови, сімейне та матеріальне благополуччя, дозвілля та медичне обслуговування, соціальний та правовий захист тощо. Методом випадкової вибірки було проведено анкетне опитування 128 військовослужбовців ВМС ЗС України, які проходили поглиблене медичне обстеження в 2019 році. В досліджувану групу ввійшли особи чоловічої статі, середній вік - 38,5 $\pm 0,44$ р., з вислугою років у ЗС України 19,68ะ0,43 р. Для вирішення поставлених завдань застосовувались наступні методи: медико-соціологічний, медико-статистичний, системний підхід.
\end{abstract}

Результати. Проведено комплексну оцінку медико-соціальних аспектів основних складових ЗСЖ у військовослужбовців ВМС ЗС України з хворобами системи кровообігу та хронічною терапевтичною патологією за результатами соціологічного опитування з застосуванням спеціально розробленої анкети. Комплексний аналіз результатів опитування дозволив виділити наступні три групи: 1 група - хворі на ХСК

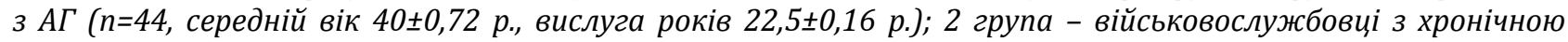

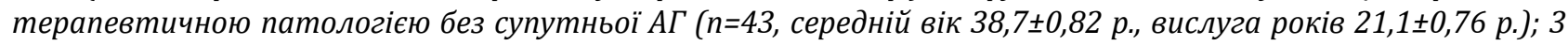

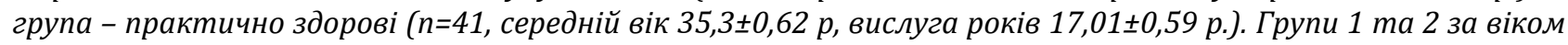
та за вислугою років достовірно не відрізнялись від групи практично здорових (p>0,05). Виявлено досить високу обізнаність військовослужбовців трьох груп щодо ЗСЖ $(86,4 \%$ 88,4\% та 95,1\% при р>0,05). Серед причин, які перешкоджають впровадженню ЗСЖ, респонденти всіх груп визначили - звички та матеріальні труднощі. Звертає на себе увагу низький рівень мотивації 1-ої та 2-ої групи, що 3,2 та 2,3 рази (6,8\% та 9,3\% відповідно) достовірно нижчий $(p<0,05)$ порівняно з рівнем мотивації у 3-ої групи $(22,0 \%)$. Досить одностайно респонденти вважали, що необхідно впровадити матеріальне заохочення $(81,8 \%, 79,1 \% \mathrm{ma}$ 70,1\% відповідно, при р>0,05) для військовослужбовців, які не мають шкідливих звичок і підтримують високий рівень здоров'я. Серед респондентів 1-ої та 2-ої групи встановлена достовірно висока поширеність куріння (56,8\% та 58,1\% проти 34,1\% відповідно при р<0,01). Вони менше дотримувалися режиму харчування $(34,1 \%$ та $37,2 \%$ проти $51,2 \%$, при р<0,05) та мали недостатню фізичну активність $(61,4 \%$, $65,1 \%$ проти 82,9\%, при р<0,01). Нормальний сон тривалістю 7-8 годин відмічало лише $11,4 \%$ респондентів 1-ої, 13,9\% -2-ої та 21,9\% - 3-ої груп (р>0,05). Більшість респондентів характеризували рівень психоемоційного навантаження на робочому місці, як високий $(63,2 \%$ респондентів 1-ої групи $p<0,01,55,8 \%$ - 2-ої групи р<0,05 проти 39,0\% 3-ої групи). Більшість респондентів трьох груп мали спільні проблеми щодо умов життя, а саме: незабезпеченість житлом, незадовільні побутові умови, низький рівень матеріального благополуччя та недостатній рівень соціального і правового захисту. Отримані дані, підтверджують необхідність проведення в першу чергу цілеспрямованих організаційних та медикоорганізаційних заходів, направлених на первинну профілактику захворювань та формування ЗСЖ у військовослужбовців ВМС ЗС України.

Висновки. Встановлено, що для військовослужбовців ВМС ЗС України типовими чинниками, що знижують рівень ЗСЖ, є порушення режиму харчування, праці та відпочинку, високий рівень шкідливих звичок та недостатній рівень фізичної активності. Виявлено, що з метою покращення підтримки ЗСЖ за даними соціологічного опитування впровадження матеріального заохочення для військовослужбовців превалює над використанням адміністративних заходів. Більшість респондентів 1-ої та 2-ої групи недооцінюють вплив на стан здоров'я способу життя (43,2\% та 46,5\%, при p>0,05) та екології (6,8\% та 
7,0\%, при р>0,05), перебільшуючи роль спадкових факторів (31,8\% та 30,2\%, при р>0,05) та медичного обслуговування (18,2\% та 16,30\%, при р<0,05). Встановлено, у військовослужбовців з ХСК та хронічною патологією, високу обізнаність щодо вимог ЗСЖ та низьке виконання даних вимог (р>0,05), низький рівень мотивації $(p<0,05)$, не дотримання режиму харчування $(p<0,05)$, нераціональне та незбалансоване харчування ( $>>0,05)$, низька фізична активність $(p<0,01)$, недотримання режиму праці та відпочинку ( $p<0,01)$, схильність до довготривалого переживання негативних емоцій ( $p<0,001)$, високий рівень психоемоційного навантаження на робочому місці ( $p<0,01$ та $p<0,05$ відповідно), високу розповсюдженість шкідливих звичок (куріння ( $<<0,01)$ та вживання алкоголю (p>0,05)) і таких факторів ризику, як надмірна вага $(p<0,05)$ у військовослужбовців з хронічною патологією та ожиріння $(p<0,001)$ у військовослужбовців 3 ХСК, що збільшує ризик ускладнень у цих осіб.

Ключові слова: військовослужбовці Військово-Морських Сил ЗС України, здоровий спосіб життя, фактори ризику.

Вступ. Збереження здоров'я та повноцінного життя громадян $€$ однією 3 найважливіших цілей світової спільноти [1]. Протягом останніх років в Україні погіршення здоров'я населення набула загрозливого рівня [2]. Особливу занепокоєність викликає погіршення стану здоров'я військовослужбовців Збройних Сил (далі - 3С) України, адже від цього значною мірою залежить обороноздатність нашої держави.

За результатами аналізу стану здоров'я за останні 5 років встановлено, що найбільший рівень загальної захворюваності характерний для Військово-Морських Сил (далі - ВМС) 3С України, що іноді майже в двічі більше узагальнених даних за всі 3С України. Враховуючи таку негативну тенденцію захворюваності серед військовослужбовців ВМС 3С України постає гостра необхідність комплексного вивчення основних складових здорового способу життя (далі - ЗСЖ) та пошуку нових превентивних (профілактичних) заходів.

Мета роботи - комплексно оцінити медико-соціальні аспекти основних складових ЗСЖ у військовослужбовців ВМС ЗС України з хворобами системи кровообігу та хронічною терапевтичною патологією для виявлення найвагоміших ризиків і розробці на цій основі сфокусованих заходів щодо їх зменшення.

Об'єкт дослідження: здоров'я військовослужбовців ВМС ЗС України.

Предмет дослідження: основні складові здорового способу життя.

Матеріали та методи дослідження. Комплексна оцінка медико-соціальних аспектів основних складових ЗСЖ у військовослужбовців ВМС 3С України була проведена за результатами соціологічного опитування 3 застосуванням спеціально розробленої анкети. Анкета включала 43 питання, що були зведені в інформаційні блоки: загальні відомості, поінформованість щодо ЗСЖ, поширеність та причини шкідливих звичок, аналіз способу життя (особливостей харчування, фізичної активності, режиму праці та відпочинку), самооцінка стану здоров'я. Також анкета містила таблицю щодо визначення, за п'яти бальною шкалою, задоволеності різними сторонами життя за наступними критеріями: умови праці та перспективи службового росту, забезпеченість житлом та побутові умови, сімейне та матеріальне благополуччя, дозвілля та медичне обслуговування, соціальний та правовий захист тощо. Опитування проводилися анонімно. При проведенні опитування респонденту докладно пояснювався зміст процедури та наголошувалось на важливість виважених та чесних відповідей. Питання сформульовані максимально конкретно та точно, не допускаючи неясності й неоднозначності запитань анкети.

Методом випадкової вибірки було проведено опитування 128 військовослужбовців ВMC $3 \mathrm{C}$ України, які проходили поглиблене медичне обстеження в 2019 році. В досліджувану групу ввійшли особи чоловічої статі, середній вік - 38,5 $\pm 0,44$

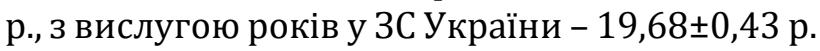

Комплексний аналіз результатів опитування дозволив виділити три групи: 1 група - хворі на хвороби системи кровообігу

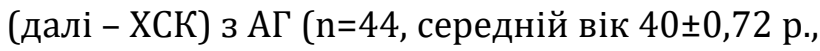

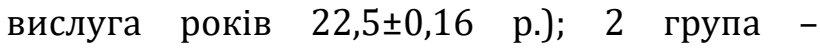
військовослужбовці 3 хронічною терапевтичною патологією без супутньої АГ (n=43, середній вік $38,7 \pm 0,82$ р., вислуга років $21,1 \pm 0,76$ р.); 3 група - практично здорові (n=41, середній вік $35,3 \pm 0,62$ р, вислуга років $17,01 \pm 0,59$ р.). Групи 1 та 2 за віком та за вислугою років достовірно не відрізнялись від групи практично здорових (p>0,05).

Застосовувались наступні методи: медико-соціологічний, медико-статистичний, системний підхід. 
Результати та їх обговорення. За результатами проведеного дослідження виявлено досить високу обізнаність військовослужбовців трьох груп щодо ЗСЖ. На запитання „Чи маєте Ви достатньо знань про здоровий спосіб життя?» позитивні відповіді було отримано від 86,4\% респондентів 1-ої групи, проти 88,4\% позитивних відповідей у 2 ій групі та 95,1\% - у 3-й, що достовірно не відрізняється $(\mathrm{p}>0,05)$ між групами в цілому. Але серед хворих з ХСК, все ж, більш висока частка військовослужбовців $(13,6 \%)$, які вважають що не мають достатньо знань про здоровий спосіб життя порівняно із практично здоровими $(4,9 \%)$.

Щодо джерел поповнення знань про здоровий спосіб життя, то $27,3 \%$ респондентів 1-ої групи вказали, що отримують нову інформацію з телевізійних передач, 25,0\% - із спеціальної літератури, $22,7 \%$ - при спілкуванні 3 лікарем, $18,2 \%$ - із статей в періодичній пресі та 6,8\% - користуються рекомендаціями знайомих. В цілому, такий же розподіл джерел поповнення знань характерний і для респондентів 2-ої та 3-ої групи (p>0,05) та співпадає 3 даними літератури $[3.4,5,6]$, що максимальний вплив на свідомість мають сучасні інформаційні технології в поєднанні 3 індивідуальним підходом.

Результатами дослідження встановлено, що абсолютна більшість військовослужбовців зважено оцінює відповідальність за стан власного здоров'я. На питання, „Як Ви вважаєте: хто несе основну відповідальність за стан Вашого здоров'я?» 84,1\% респондентів 1ої групи груп відповіли - „Я особисто», респонденти 2-ої та 3-ої групи 86,0\% та 90,3\% відповідно. 9,0\% респондентів 1-ої, 7,0\% - 2-ої групи та 4,9\% - 3-ої групи відповідальність покладають на медичних працівників, 3,6\%, $4,7 \%$ і 2,4\% відповідно на командування та лише 2,3\%, 2,3\% та 2,4\% відповідно на сім'ю $(\mathrm{p}>0,05)$.

Аналіз оцінки обізнаності військовослужбовців щодо загальновизнаних основних чинників, які впливають на стан здоров'я показав, що більшість опитаних військовослужбовців 3 ХСК (1-а група) недостатньо обізнані з даного питання.

Спосіб життя, як найвагоміший фактор який впливає на стан здоров'я, на перше місце ставлять $\quad 43,2 \%$ хворих 3 ХСК, 46,5\% 3 хронічною патологією та 51,2\% практично здорових військовослужбовців ( $>0,05)$, спадковість - 31,8\%, 30,2\% та $26,9 \%$ відповідно (р>0,05). Респонденти 1-ої та 2-ої групи недооцінили вплив навколишнього середовища на стан здоров'я у порівнянні 3 респондентами 3-ої групи (p>0,05). Проте, військовослужбовці, які хворіють на ХСК та 3 хронічною патологію, достовірно $(\mathrm{p}<0,05)$ значно більшу роль приділяють медичному обслуговуванню у якості чинника, який впливає на стан здоров'я, ніж практично здорові військовослужбовці.

Отриманий нами розподіл відповідей серед здорових військовослужбовців в більшій мірі співпадає із вищенаведеними даними, більшість ж респондентів з ХСК та з хронічною патологією недооцінюють вплив на стан здоров'я способу життя та вплив екології, перебільшуючи роль спадкових факторів та медичного обслуговування.

Отримані результати дослідження показали невідповідність між рівнем поінформованості військовослужбовців щодо основних вимог ЗСЖ та їх практичним виконанням (рис. 1).

Так, оцінюючи за п'ятибальною шкалою виконання рекомендацій щодо ЗСЖ, більшість респондентів 1-ої та 2-ої групи (61,4\% та 62,8\% відповідно) оцінили себе на три бали, в той час як респонденти 3-ої групи тільки 43,9\% $(\mathrm{p}<0,05)$. На чотири бали оцінили виконання рекомендацій щодо ЗСЖ респонденти 1-ої та 2 -ої групи тільки $11,4 \%$ та $14,0 \%$, в той час як респонденти 3-ої групи 41,5\% (p<0,01). На два бали достовірно більше оцінили себе респонденти 1-ої групи $(18,2 \%)$ у порівнянні 3 респондентами 3-ої групи 4,8\% (p<0,05).

Серед причин, які перешкоджають впровадженню ЗСЖ, опитані нами військовослужбовці всіх груп визначили звички та матеріальні труднощі. При цьому респонденти 1-ої групи та 2-ої групи частіше $(54,6 \%$ та $48,9 \%)$ вказували на звички $(\mathrm{p}<0,05)$, а практично здорові $(39,0 \%)$ - на матеріальні труднощі $(\mathrm{p}<0,05)$.

Важливо зауважити, що відсутність знань, як основна причина, що заважає впроваджувати здоровий спосіб життя, достовірно характерна для більшої кількості військовослужбовців 1-ої та 2-ої групи, ніж військовослужбовців 3-ої групи $(13,6 \%$ та 16,3\% проти 2,4\% відповідно, при р<0,05). 


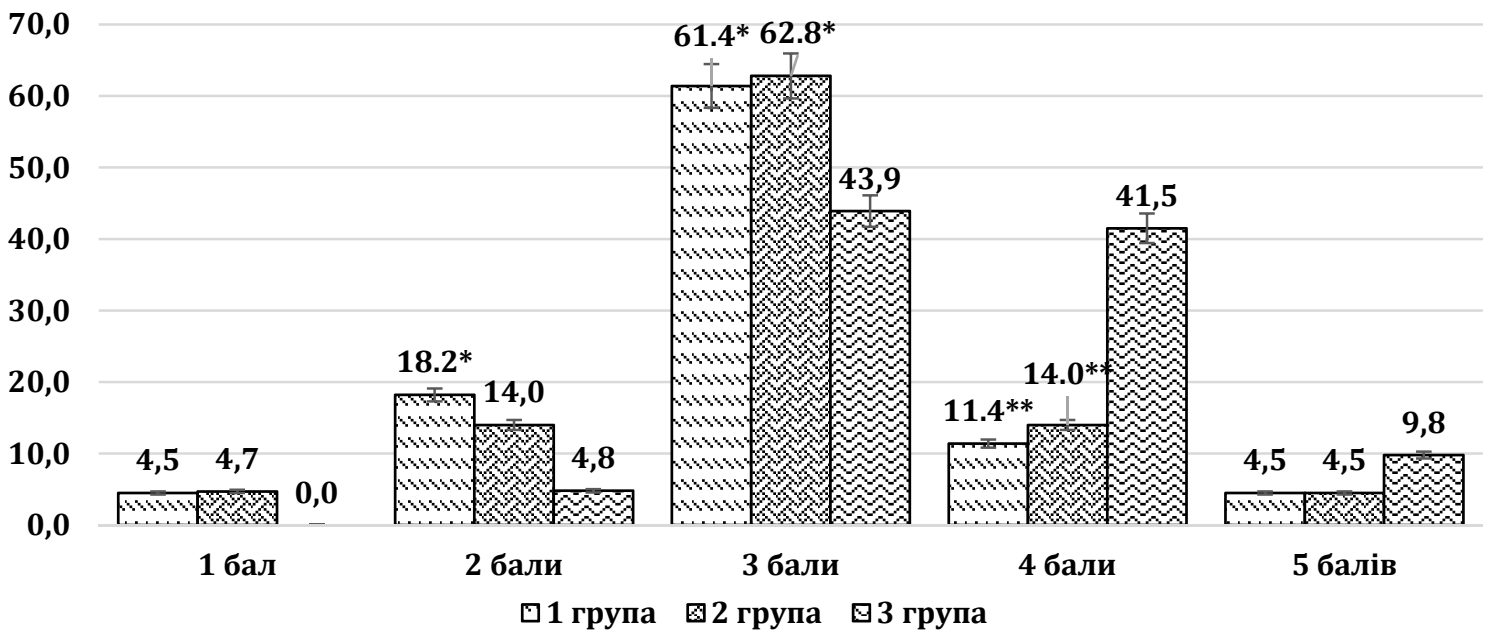

Примітка: *,** - достовірність різниці у порівнянні з 3-ю групою за критерієм Стьюдента відповідає рівню $\mathrm{p}<0,05, \mathrm{p}<0,01$

Рисунок 1. Суб’єктивна оцінка за 5-ти бальною шкалою виконання вимог здорового способу життя військовослужбовцями 3 АГ (1 група, $\mathrm{n}=44), 3$ хронічною терапевтичною патологією (2 група, $\mathrm{n}=43$ ) та практично здоровими військовослужбовцями (3 група, $\mathrm{n}=41)$, \%.

Звертає на себе увагу низький рівень мотивації 1-ої та 2-ої групи, що 3,2 та 2,3 рази (6,8\% та 9,3\% відповідно) достовірно нижчий $(\mathrm{p}<0,05)$ порівняно 3 рівнем мотивації у практично здорових військовослужбовців $(22,0 \%)$.Досить одностайно групи вважають що необхідно впровадити матеріальне заохочення $(81,8 \%, 79,1 \%$ та $70,1 \%$ відповідно, при $р>0,05$ ) для військовослужбовців, які не мають шкідливих звичок i підтримують високий рівень здоров'я. Крім цього, між групами не виявлено достовірної різниці у показниках, щодо використання адміністративних заходів для спонукання військовослужбовців до ведення ЗСЖ $(47,7 \%$, 48,8\% проти 53,7\% відповідно, при р>0,05) та необхідності підвищення рівня пропаганди ЗСЖ у ВМС 3С України $(88,6 \%, 86,0 \%$ проти 85,4\% відповідно, при р>0,05).

Наступним блоком запитань, ми проводили аналіз поширеності серед військовослужбовців шкідливих звичок куріння (табл. 1) та прийому алкогольних напоїв (табл. 2).

Таблиця 1

Розподіл респондентів щодо відношення до куріння, \%

\begin{tabular}{|l|c|c|c|}
\hline \multicolumn{1}{|c|}{ Статус } & $\begin{array}{c}1 \text { група } \\
(\mathrm{n}=44)\end{array}$ & $\begin{array}{c}2 \text { група } \\
(\mathrm{n}=43)\end{array}$ & $\begin{array}{c}3 \text { група } \\
(\mathrm{n}=41)\end{array}$ \\
\hline Курять & $56,8^{* *}$ & $58,1^{* *}$ & 34,1 \\
\hline Курили в минулому & 18,2 & 16,3 & 24,4 \\
\hline Не курять & $25,0^{*}$ & $25,6^{*}$ & 41,5 \\
\hline Викурюють: & & & \\
- до 10 цигарок на добу & $35,6(\mathrm{n}=33)$ & $46,5(\mathrm{n}=32)$ & $42,3(\mathrm{n}=24)$ \\
- 11-20 цигарок на добу & $60,6(\mathrm{n}=33)$ & $50,3(\mathrm{n}=32)$ & $55,1(\mathrm{n}=24)$ \\
- 21і більше цигарок на добу & $3,8(\mathrm{n}=33)$ & $3,2(\mathrm{n}=32)$ & $2,6(\mathrm{n}=24)$ \\
\hline Курять: & & & \\
- менше 10 років & $36,4(\mathrm{n}=33)$ & $34,5(\mathrm{n}=32)$ & $46,6(\mathrm{n}=24)$ \\
- 11-20 років & $58,2(\mathrm{n}=33)$ & $59,7(\mathrm{n}=32)$ & $52,1(\mathrm{n}=24)$ \\
- 21 рік більше & $5,4(\mathrm{n}=33)$ & $5,8(\mathrm{n}=32)$ & $1,3(\mathrm{n}=24)$ \\
\hline Курять: & & & \\
- через залежність & $32,1(\mathrm{n}=33)$ & $25,6(\mathrm{n}=32)$ & $21,8(\mathrm{n}=24)$ \\
- за компанію & $2,2(\mathrm{n}=33)$ & $2,1(\mathrm{n}=32)$ & $4,8(\mathrm{n}=24)$ \\
- для зняття психоемоційного напруження & $54,9(\mathrm{n}=33)$ & $51,6(\mathrm{n}=32)$ & $51,2(\mathrm{n}=24)$ \\
- для скорочення часу & $6,1(\mathrm{n}=33)$ & $5,8(\mathrm{n}=32)$ & $5,4(\mathrm{n}=24)$ \\
- не можуть пов'язати причину куріння & $4,7^{*}(\mathrm{n}=33)$ & $14,9(\mathrm{n}=32)$ & $16,8(\mathrm{n}=24)$ \\
\hline Вважають, що куріння шкодить здоров'ю & $95,3(\mathrm{n}=33)$ & $89,5(\mathrm{n}=32)$ & $93,1(\mathrm{n}=24)$ \\
\hline Мають бажання кинути курити & $71,6(\mathrm{n}=33)$ & $73,4(\mathrm{n}=32)$ & $75,6(\mathrm{n}=24)$ \\
\hline Раніше мали спроби кинути курити & $66,6(\mathrm{n}=33)$ & $62,1(\mathrm{n}=32)$ & $56,8(\mathrm{n}=24)$ \\
\hline
\end{tabular}

Примітка. * ** - вірогідність різниці у порівнянні з 3-ою групою, p<0,05, p<0,01. 
Виявлено відносно високу частоту поширеності куріння серед респондентів всіх груп, але серед респондентів 1-ої та 2-ої груп ця шкідлива звичка зустрічається достовірно $(\mathrm{p}<0,01)$ частіше, ніж у практично здорових (56,8\% та $58,1 \%$ проти $34,1 \%$ відповідно). Аналіз поширеності куріння серед обстежуваного контингенту показав, що по кількості викурених цигарок частіше зустрічалися особи, які викурюють 11-20 цигарок на добу $(60,6 \%$ в 1-ій групі, $50,3 \%$ в 2ій та 55,1\% в 3-ій групі, при р> 0,05). Крім того, виявлено значний стаж куріння, 58,2\% військовослужбовців в 1-й, 59,7\% - у 2-й та $52,1 \%$ в 3-і групі палять від 11 до 20 років (при $\mathrm{p}>0,05$ ).

Аналіз чинників, що спонукають військовослужбовців до куріння показав, що основними причинами в трьох групах це

зняття психоемоційного напруження $(54,9 \%$, $51,6 \%$ та $51,2 \%$ відповідно при $р>0,05$ ). Залежність визнають $-32,1 \%$ респонденти 1-ої групи, 25,6\% - 2-ої та 21,8\% - 3-ої (р>0,05). Значна кількість $(16,8 \%)$ практично здорових військовослужбовців, не могли визначити причину куріння, в той же час, таких з ХСК достовірно $(\mathrm{p}<0,05)$ менше $(4,7 \%)$. Слід відмітити, що всі респонденти $(95,3 \%, 89,5 \%$ та 93,1\% відповідно) 3 достатнім статусом куріння вважають, що це шкодить їх здоров'ю (p>0,05), 71,6\%, 73,4\% та 75,6 \% бажають кинути палити $(\mathrm{p}>0,05)$. При цьому відповідно $66,6 \%, 62,1$ та 56,8\% (p>0,05) раніше мали спроби кинути палити (табл. 1).

Іншим важливим фактором, який негативно впливає виникнення та перебіг ХСК та більшості хронічних захворювань $\epsilon$ алкоголь (табл. 2).

Таблиця 2

Розподіл респондентів щодо відношення до алкоголю, \%

\begin{tabular}{|l|c|c|c|}
\hline \multicolumn{1}{|c|}{ Статус } & $\begin{array}{c}1 \text { група } \\
(\mathrm{n}=44)\end{array}$ & $\begin{array}{c}2 \text { група } \\
(\mathrm{n}=43)\end{array}$ & $\begin{array}{c}3 \text { група } \\
(\mathrm{n}=41)\end{array}$ \\
\hline Вживають алкогольні напої & 90,9 & 88,3 & 87,8 \\
\hline - щоденно & $0(\mathrm{n}=40)$ & $0(\mathrm{n}=38)$ & $0(\mathrm{n}=36)$ \\
- 2-3 рази на тиждень & $10,0(\mathrm{n}=40)$ & $7,9(\mathrm{n}=38)$ & $2,8(\mathrm{n}=36)$ \\
- у вихідні дні та святкові дні & $70,0^{* *}(\mathrm{n}=40)$ & $71,1^{* *}(\mathrm{n}=38)$ & $41,7(\mathrm{n}=36)$ \\
- 1 раз на місяць & $17,5^{* *}(\mathrm{n}=40)$ & $15,8^{* *}(\mathrm{n}=38)$ & $38,9(\mathrm{n}=36)$ \\
- 3-4 рази на рік & $2,5^{*}(\mathrm{n}=40)$ & $5,2^{*}(\mathrm{n}=38)$ & $16,6(\mathrm{n}=36)$ \\
\hline Не вживають алкогольні напої & 9,1 & 11,7 & 12,2 \\
\hline
\end{tabular}

Примітка. ${ }^{* * *}$ - вірогідність різниці у порівнянні з 3-ою групою, p<0,05, p<0,01.

Достовірної різниці (p>0,05) щодо визнання вживання алкоголю у всіх трьох групах не встановлено. При цьому достовірно більше $(\mathrm{p}<0,01)$ респондентів 1-ої та 2-ої групи (70,0\% та 71,1\% відповідно), у порівнянні з 3ю групою $(41,7 \%)$, вживають алкогольні напої у вихідні та святкові дні. При цьому в 1-й групі у 2,2 рази $(17,5 \%)$ достовірно менше респондентів вживають алкоголь 1 раз на місяць та в 6,6 разів (2,5\%) достовірно менше вживають алкоголь 3-4 раз на рік у порівнянні з 3-ю групою $(38,9 \%$ при р $<0,01$ та $16,6 \%$ при $\mathrm{p}<0,05$ відповідно). Така ж тенденція і в 2-й групі - в 2,5 рази $(15,8 \%)$ достовірно менше респондентів вживають алкоголь 1 раз на місяць та в 3,2 рази $(5,2 \%)$ достовірно менше вживають алкоголь 3-4 раз на рік у порівнянні з 3-ю групою $(38,9 \%$ при р $<0,01$ та $16,6 \%$ при р<0,05 відповідно).

Таким чином, незважаючи на вимоги „Статуту внутрішньої служби Збройних Сил України», яким передбачено утримання військовослужбовців від шкідливих звичок, в нашому досліджені, за результатами анонімного опитування, було визначено високий рівень нікотинової залежності та вживання спиртних напоїв.

Наступним блоком питань ми проводили детальний аналіз способу життя: особливостей харчування (табл. 3), фізичної активності, режиму праці та відпочинку (табл. 4).

Респонденти 1-ої та 2-ої групи достовірно менше дотримуються режиму харчування ніж респонденти 3 -ої групи $(34,1 \%$ та $37,2 \%$ проти $51,2 \%$, при р<0,05). Незначна кількість респондентів трьох груп вважають, харчування раціональним та збалансованим $(22,7 \%, 23,2 \%$ та 31,7\%, при р>0,05). Більшість респондентів харчуються 2-3 рази на добу, однак, цей показник достовірно менший у 1-ої та 2-ої групи у порівнянні з показником 3-ої групи $(50,0 \%$ та $53,5 \%$ проти $68,3 \%$, при $\mathrm{p}<0,05)$. Достовірно частіше респонденти 1-ої та 2-ої групи харчуються 1-2 рази на добу (36,4\% та $30,2 \%$ відповідно) в той час як у практично здорових цей показник становить тільки $2,4 \%(\mathrm{p}<0,001)$. 
Розподіл респондентів щодо особливостей харчування, \%

\begin{tabular}{|c|c|c|c|}
\hline Частота & $\begin{array}{l}1 \text { група } \\
(\mathrm{n}=44)\end{array}$ & $\begin{array}{c}2 \text { група } \\
(\mathrm{n}=43)\end{array}$ & $\begin{array}{l}3 \text { група } \\
(\mathrm{n}=41)\end{array}$ \\
\hline Дотримуються режиму харчування & $34,1^{*}$ & $37,2^{*}$ & 51,2 \\
\hline $\begin{array}{ll}\text { Вважають, харчування } \\
\text { раціональним }\end{array}$ & 22,7 & 23,2 & 31,7 \\
\hline $\begin{array}{l}\text { Харчуються: } \\
\text { - 3-4 рази на добу } \\
\text { - 2-3 рази на добу } \\
\text { - 1-2 рази на добу }\end{array}$ & $\begin{array}{c}13,6^{*} \\
50,0^{*} \\
36,4^{* * *}\end{array}$ & $\begin{array}{c}16,3 \\
53,5^{*} \\
30,2^{* *}\end{array}$ & $\begin{array}{c}29,3 \\
68,3 \\
2,4\end{array}$ \\
\hline Основний прийом їжі у вечірні години & $79,5^{*}$ & $81,4^{* *}$ & 60,9 \\
\hline $\begin{array}{l}\text { В харчуванні надає перевагу: } \\
\text { - гострим, соленим, консервованим продуктам } \\
\text { - жирним, жареним, копченим продуктам } \\
\text { - виробам з тіста, солодощам } \\
\text { - дієтичним стравам }\end{array}$ & $\begin{array}{c}25,0 \\
52,3 \\
15,9 \\
6,8\end{array}$ & $\begin{array}{c}25,6 \\
53,5 \\
13,9 \\
7,0\end{array}$ & $\begin{array}{c}14,6 \\
63,4 \\
9,7 \\
12,3\end{array}$ \\
\hline $\begin{array}{l}\text { Щоденно вживає овочів і фруктів: } \\
\text { - } 400 \text { г і більше } \\
\text { - 200-400 г } \\
\text { - 100-200 г } \\
\text { - менше } 100 \text { г }\end{array}$ & $\begin{array}{c}4,5 \\
25,0^{*} \\
54,5 \\
16,0^{*}\end{array}$ & $\begin{array}{c}7,0 \\
27,9^{*} \\
55,8 \\
9,3\end{array}$ & $\begin{array}{c}12,2 \\
44,0 \\
39,0 \\
4,8\end{array}$ \\
\hline
\end{tabular}

Примітка. ${ }^{* * *}, * * *$ - вірогідність різниці у порівнянні з 3-ою групою, p<0,05, p<0,01, p<0,001.

Встановлено, що 14,3\% респондентів 1-ої достовірно рідше у порівнянні з 3-ю групою, дотримуються 3-4 разового режиму харчування $(13,6 \%$ проти $29,3 \%$, при р<0,05). При цьому основний прийом їжі припадає на вечірні години в 1-й групі відмітили 79,5\% та $81,4 \%$ 2-й групах проти 60,9\% в 3-й (при р<0,05 та р <0,01 відповідно).

$25,0 \%$ респондентів 1-ої, 25,6\% - 2-ої групи та $14,6 \%$ - 3-ої групи у своєму харчуванні надають перевагу гострим, соленим та консервованим продуктам; більшість опитаних респондентів (52,3\%, $53,5 \%$ та $63,4 \%$ відповідно) - жирним, жареним, копченим продуктам; виробам 3 тіста, кондитерським виробам та солодощам надають перевагу 15,9\%, 13,9\% та 9,7\% відповідно. Лише 6,8\% військовослужбовців 3 ХСК, 7,0\% - з хронічними захворюваннями та $12,3 \%$ в групі практично здорових дотримується дієтичного харчування (при $\mathrm{p}>0,05$ ).

Аналіз даних добового споживання військовослужбовцями овочів та фруктів дозволив встановити, що понад 400 г корисних продуктів щоденно споживає лише 4,5\% респондентів 1-ї групи, 7,0\% - 2-ї та 12,2\% - 3ї; 200-400 г - 25,0\%, 27,9\% та 39,0\% відповідно $(\mathrm{p}<0,05)$. Більше половини опитаних респондентів 1-ї та 2-ї груп (54,5\% та 55,8\% відповідно) щоденно споживає 100-200 г овочів та фруктів (p>0,05). В той час, як $16,0 \%$ респондентів 1-ї групи споживає менше 100 г овочів та фруктів протягом дня, що в 3,3 рази менше ніж у респондентів 3 -ї групи $(4,8 \%$, при $\mathrm{p}<0,05$ ).

Детальний аналіз особливостей фізичної активності, режиму праці та відпочинку подано у табл. 4.

При ретельному вивчені тривалості робочого дня у респондентів, встановлено понаднормову зайнятість військовослужбовців. Близько третини (34,1\%, 27,9\% та 29,0\% відповідно, при р>0,05) військовослужбовців трьох груп вказує, що працює по 12 годин і більше. Ще 43,2\% респондентів 1-ої, 46,5\% - 2-ої групи та $34,4 \%$ 3-ої групи (p>0,05) проводить щоденно на службі 10-11 годин, та лише у $22,7 \%$ та $25,6 \%$ проти 36,6\% відповідно, при р>0,05 тривалість робочого дня складає 8-9 годин. При цьому, майже половина опитаних військовослужбовців відзначила, що мають 6 денний робочий тиждень та лише один вихідний день - 45,4\% респондентів 1-ої, 46,5\% - 2-ої та 39,0\% 3-ої групи (p>0,05).

Враховуючи, що значна кількість респондентів відмічає понаднормову працю та 6 денний робочий тиждень, на запитання „Чи дотримуєтесь Ви режиму праці й відпочинку?» позитивну відповідь дали $29,5 \%$ респондентів 1-ої групи, 32,5\% - 2-ої проти 56,1 \% - 3-ої $(\mathrm{p}<0,01)$. 
Таблиця 4

Розподіл респондентів щодо фізичної активності, режиму праці та відпочинку, \%

\begin{tabular}{|l|c|c|c|}
\hline \multicolumn{1}{|c|}{ Частота } & $\begin{array}{c}1 \text { група } \\
\text { (n=44) }\end{array}$ & $\begin{array}{c}2 \text { група } \\
\text { (n=43) }\end{array}$ & $\begin{array}{c}3 \text { група } \\
\text { (n=41) }\end{array}$ \\
\hline Дотримуються режиму праці та відпочинку & $29,5^{* *}$ & $32,5^{* *}$ & 56,1 \\
\hline $\begin{array}{l}\text { Регулярно відпочивають у вихідні дні та під час } \\
\text { відпустки }\end{array}$ & 40,9 & 41,8 & 41,4 \\
\hline Займаються фізичними вправами & $61,4^{* *}$ & $65,1^{*}$ & 82,9 \\
\hline Займаються спортом в теперішній час & $18,1^{*}$ & $18,6^{*}$ & 34,4 \\
\hline Займалися спортом раніше & $45,5^{*}$ & $41,8^{*}$ & 61,0 \\
\hline Середня тривалість сну: & & & 22,0 \\
- до 6 годин на добу & 25,0 & 25,6 & 56,1 \\
- 6-7 годин & 63,6 & 60,5 & 21,9 \\
- 7-8 годин & 11,4 & 13,9 & 36,6 \\
\hline Тривалість робочого дня: & & & 34,4 \\
- 8-9 годин & 22,7 & 25,6 & 29,0 \\
- 10-11 годин & 43,2 & 45,5 & 61,0 \\
- 12 і більше годин & 34,1 & 27,9 & 39,0 \\
\hline Тривалість робочого тижня: & & & \\
- 5 днів & 54,6 & 53,5 & 46,5 \\
- 6 днів & 45,4 & & \\
\hline
\end{tabular}

Примітка. * **, *** - вірогідність різниці у порівнянні з 3-ою групою, p<0,05, p<0,01, p<0,001.

Важливим чинником зміцнення здоров'я та попередження захворювань є можливість повноцінного відпочинку. Під час дослідження встановлено, що менше третини військовослужбовців трьох груп (40,9\%, 41,8\% та 51,2\% відповідно, при р>0,05), регулярно відпочивають у вихідні дні та під час відпустки.

В результаті вивчення характеру сну, як одного з показників стану нервової діяльності і психологічного комфорту, встановлено, що нормальний сон тривалістю 7-8 годин відмічає лише 11,4\% респондентів 1-ої, 13,9\% -2-ої та 21,9\% - 3-ої груп, тривалість сну 6-7 годин 63,6\%, 60,5\% та 56,1\% відповідно, менше 6 годин - 25,0\% респондентів 1-ої, 25,6\% - 2-ої проти 22,0\% 3-ої групи. Достовірної різниці між показниками тривалості сну у групах ми не отримали ( $>>0,05)$.

Проведена оцінка фізичної активності військовослужбовців показала, що для військовослужбовців 1-ої та 2-ої групи характерна недостатня фізична активність. На запитання „Чи займаєтесь Ви фізичними вправами?» позитивні відповіді було отримано від 61,4\% респондентів 1-ої групи та 65,1\% респондентів 2-ої групи проти 82,9\% позитивних відповідей у 3-і групі $(\mathrm{p}<0,01)$. При цьому зараз спортом займаються 18,1\% військовослужбовців у 1-й групі проти 34,4\% у 3 -й $(\mathrm{p}<0,05)$.

Звертає на себе увагу факт насиченості життя військовослужбовців стресами.
Більшість респондентів характеризує рівень психоемоційного навантаження на робочому місці, як високий $(63,2 \%$ респондентів 1-ої групи р<0,01, 55,8\% - 2-ої групи р<0,05 проти 39,0\% 3-ої групи) та помірний (34,1\% при р<0,05, 40,1\% та 48,8\% відповідно).

Із наукової літератури відомо, що умови праці, які потребують високої психічної активності, супроводжуються зростанням рівня емоційної напруги, тривожності можуть бути віднесені до факторів, які сприяють розвитку психосоматичної патології $[7,8,9$, 10]. Схильність до довготривалого переживання негативних емоцій на доданок до високого психоемоційного навантаження $€$ підгрунтям для виникнення великого різноманіття захворювань. В ході соціологічного опитування встановлено, що респонденти з ХСК та хронічною патологією схильні до довготривалого переживання негативних емоцій. Так, довготривалі переживання відмічають $65,9 \%$ респондентів 1-ої групи, 58,1\% - 2-ої групи, в той час як тільки 26,8\% практично здорові (p<0,001). Діаметрально протилежні дані у респондентів 3-ої групи, які достовірно менше схильні до довготривалого переживання негативних емоцій $(\mathrm{p}<0,001)$.

3 метою формування більш повної картини про стан здоров'я військовослужбовців була оцінена суб'єктивна думка респондентів трьох груп щодо стану власного здоров'я (рис 2). 


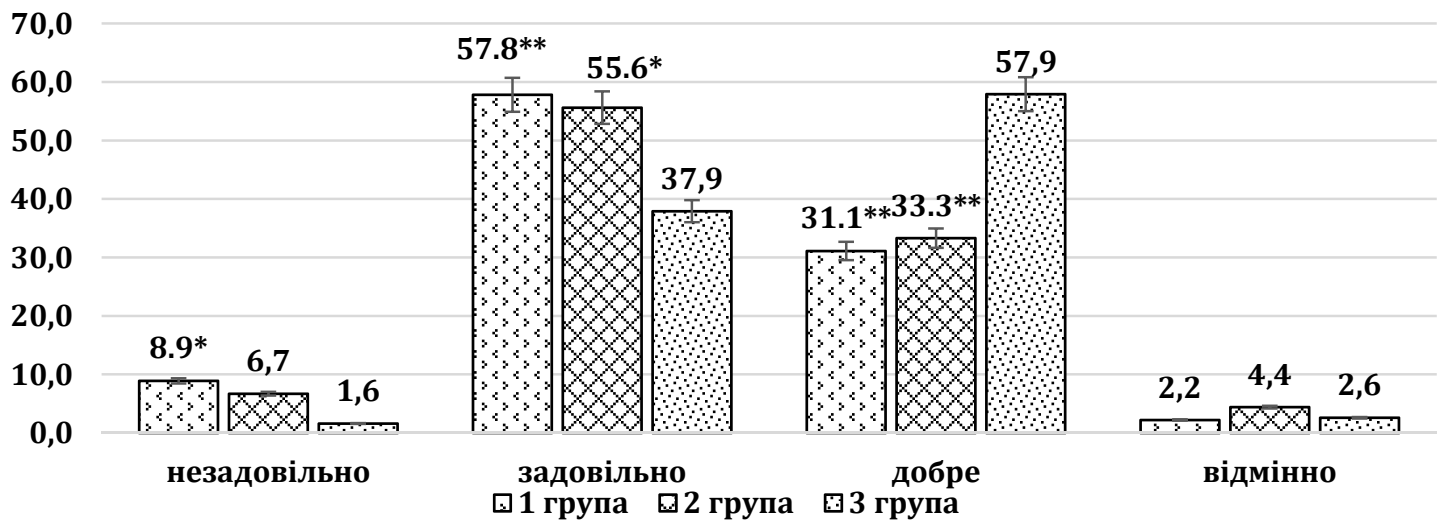

Примітка. *,* - вірогідність різниці у порівнянні з 3-ою групою, p<0,05, p<0,01.

Рисунок 2. Суб'єктивна оцінка стану здоров'я військовослужбовцями з ХСК (1 група, n=44), 3 хронічною терапевтичною патологією (2 група, $\mathrm{n}=43$ ) та практично здоровими військовослужбовцями (3 група, $\mathrm{n}=41), \%$

3 наведених даних на рис. 2 видно, що найбільш часто респонденти 1-ої та 2-ої групи оцінюють стан здоров'я як „задовільний» $(57,8 \%$ при $\mathrm{p}<0,01$ та $55,6 \%$ при $\mathrm{p}<0,05$ відповідно) у порівнянні 3 практично здоровими $\quad(37,9 \%)$. Тільки третина респондентів 1-ої та 2-ої групи оцінюють стан здоров'я як „добрий» $(31,1 \%$ та $33,3 \%$ відповідно), в той час як респонденти 3-ої групи у 57,9\% (р<0,01). Слід відмітити, що 8,9\% респондентів 1-ої групи оцінюють стан здоров'я, як „незадовільний», що достовірно $(\mathrm{p}<0,05)$ більше, ніж серед представників 3-ої групи $(1,6 \%)$.

За даними соціологічного опитування середні показники маси тіла у військовослужбовців 3 ХСК становили $29,3 \pm 0,49$, що достовірно ( $<<0,001)$ вище, ніж у здорових осіб та осіб з хронічною патологією

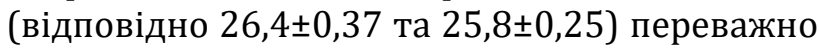
за рахунок більшої частки $(\mathrm{p}<0,001)$ ожиріння 1-ої стадії (табл. 5).

Розподіл військовослужбовців трьох груп за величиною індексу маси тіла, $(\mathrm{n}=128)$ \%

\begin{tabular}{|c|c|c|c|c|}
\hline $\begin{array}{l}\text { № } \\
\text { 3/п }\end{array}$ & Показники & $\begin{array}{c}1 \text { група } \\
(\mathrm{n}=44)\end{array}$ & $\begin{array}{c}2 \text { група } \\
(\mathrm{n}=43)\end{array}$ & $\begin{array}{c}3 \text { група } \\
(\mathrm{n}=41)\end{array}$ \\
\hline 1. & Нормальна маса тіла, IMT < 25 кг/м² & $20,5^{* * *}$ & $34,8^{*}$ & 51,2 \\
\hline \multirow[t]{5}{*}{2.} & Перевищення IMT > 25 кг/м²: & $79,5^{* * *}$ & $65,2^{*}$ & 48,8 \\
\hline & - надмірна вага & 38,6 & 55,9 & 44,0 \\
\hline & - ожиріння 1-ої стадії & $34,1^{* * *}$ & 9,3 & 4,8 \\
\hline & - ожиріння 2-ої стадії & 6,8 & 0 & 0 \\
\hline & - ожиріння 3-ої стадії & 0 & 0 & 0 \\
\hline
\end{tabular}

Примітка. ${ }^{* * *},{ }^{* * *}$ - вірогідність різниці у порівнянні з 3-ою групою, $\mathrm{p}<0,05, \mathrm{p}<0,01, \mathrm{p}<0,001$.

Встановлено, що переважна більшість військовослужбовців 3-х груп проходить профілактичні огляди. Лише $13,6 \%$ респондентів 1-ої групи, 13,9\% - 2-ої та 12,2\% групи практично здорових не змогли вказати дату останнього профілактичного огляду $(\mathrm{p}>0,05)$

Слід відмітити, що лише $38,6 \%$ респондентів 1-ої групи та 41,9\% - 2-ої групи вказали, що перебувають під диспансернодинамічним спостереженням, в той час, як серед респондентів 3-ої групи таких 7,3\% $(\mathrm{p}<0,001)$. Такий стан справ може бути обумовлений поінформованістю військовослужбовців, щодо системи диспансерного обліку.

Проведено аналіз задоволеності респондентами різними сторонами свого життя, від яких може залежати самопочуття людей (табл. 6). В результаті досліджень, встановлено, що більшість військовослужбовців трьох груп мають спільні проблеми щодо умов життя. А саме: незабезпеченість житлом, незадовільні побутові умови, низький рівень матеріального благополуччя та недостатній рівень соціального і правового захисту. Близько половини військовослужбовців трьох груп в ті, 
чи іншій мірі задоволені роботою, харчуванням, проведенням

відпочинку та перспективами службового зростання, медичним обслуговуванням.

Таблиця 6

Розподіл військовослужбовців щодо задоволеності різними сторонами життя за 5-ти бальною шкалою

\begin{tabular}{|c|c|c|c|c|c|c|c|c|c|c|c|c|c|c|c|}
\hline \multirow[t]{2}{*}{ Сторони життя } & \multicolumn{5}{|c|}{$\begin{array}{c}1 \text { група } \\
(\mathrm{n}=44)\end{array}$} & \multicolumn{5}{|c|}{$\begin{array}{l}2 \text { група } \\
(\mathrm{n}=43)\end{array}$} & \multicolumn{5}{|c|}{$\begin{array}{c}3 \text { група } \\
(\mathrm{n}=41)\end{array}$} \\
\hline & 1 & 2 & 3 & 4 & 5 & 1 & 2 & 3 & 4 & 5 & 1 & 2 & 3 & 4 & 5 \\
\hline $\begin{array}{c}\text { Робота } \\
\text { (характер } \\
\text { праці, умови, } \\
\text { можливості та } \\
\text { ін.) }\end{array}$ & 4,5 & 18,2 & 41,0 & 31,8 & $4,5^{*}$ & 4,7 & 16,3 & 37,1 & 32,6 & 9,3 & 2,4 & 9,8 & 29,2 & 41,5 & 17,1 \\
\hline $\begin{array}{r}\text { Перспек } \\
\text { службо } \\
\text { зроста }\end{array}$ & 15,9 & 20,5 & $36,3^{*}$ & $20,5^{*}$ & 6,8 & 16,3 & 25,6 & 27,8 & 23,3 & 7,0 & 12,2 & 14,6 & 22,0 & 36,6 & 14,6 \\
\hline $\begin{array}{r}\text { Забезпе } \\
\text { жит }\end{array}$ & 25,0 & 18,2 & 27,3 & 22,7 & 6,8 & 20,1 & 14,0 & 35,6 & 23,3 & 7,0 & 14,6 & 14,6 & 31,1 & 27,5 & 12,2 \\
\hline Побутові ул & 11,4 & 13,6 & $47,7^{*}$ & $18,2^{*}$ & \begin{tabular}{|l|l|}
9, \\
\end{tabular} & 9,3 & 9,3 & 37,5 & 29,3 & 14,6 & 4,9 & 7,3 & 29,3 & 39,0 & 19,5 \\
\hline $\begin{array}{r}\text { Мате } \\
\text { благо } \\
\end{array}$ & 11,4 & 13,6 & 34,1 & 29,5 & 11,4 & 11,6 & 11,6 & 30,3 & 30,2 & 16,3 & 4,9 & 7,3 & 29,3 & 41,4 & 17,1 \\
\hline $\begin{array}{c}\text { Відношення у } \\
\text { сім'ї }\end{array}$ & 4,5 & 2,3 & 18,2 & 38,6 & 36,4 & 2,3 & 2,3 & 21,0 & 39,5 & 34,9 & 2,4 & 2,4 & 12,3 & 39,0 & 43,9 \\
\hline $\begin{array}{r}\text { Діти: i } \\
\text { здоров'ء } \\
\text { благопол } \\
\end{array}$ & 6,8 & 6,8 & 27,3 & 40,9 & 18,2 & 7,0 & 9,3 & 32,6 & 32,5 & 18,6 & 2,4 & 4,9 & 22,0 & 43,9 & 26,8 \\
\hline Харчування & 6,8 & 9,1 & 45,5 & 29,5 & 9,1 & 4,7 & 9,3 & 44,2 & 30,2 & 11,6 & 0 & 4,9 & 41,5 & 41,5 & 12,1 \\
\hline $\begin{array}{c}\text { Дозвілля, } \\
\text { відпочинок, } \\
\text { розваги }\end{array}$ & 6,8 & 20,6 & 40,9 & 24,9 & 6,8 & 4,6 & 20,9 & 34,9 & 28,0 & 11,6 & 2,4 & 19,5 & 31,7 & 31,8 & 14,6 \\
\hline $\begin{array}{c}\text { Медичне } \\
\text { обслуговування }\end{array}$ & 4,5 & 22,7 & 45,5 & $20,5^{*}$ & 6,8 & 4,6 & 18,6 & 41,9 & 25,6 & 9,3 & 0 & 12,2 & 39,0 & 36,6 & 12,2 \\
\hline $\begin{array}{c}\text { Соціальний та } \\
\text { правовий } \\
\text { захист } \\
\end{array}$ & 25,0 & 27,3 & 40,9 & 6,8 & 0 & 23,3 & 25,6 & 37,2 & 11,6 & 0 & 26,8 & 24,4 & 36,6 & 9,8 & 2,4 \\
\hline
\end{tabular}

Примітка. ${ }^{*}$ - вірогідність різниці у порівнянні з 3-ою групою, $\mathrm{p}<0,05$.

В той же час, більшість респондентів задоволені відношенням у сім'ї, здоров'ям та благополуччям дітей (аналіз сімейного стану респондентів свідчить про досить значну частку одружених військовослужбовців (81,8\% в 1-й групі та 88,4\% - 2-й та $92,7 \%$ - 3й) та незначну частку неодружених $(4,5 \%$, $2,3 \%$ i 2,4\% відповідно) та розведених (вдівців) відповідно - 13,7\%, 9,3\% та 4,9\%. Достовірної різниці між групами щодо сімейного стану не встановлено ( $>0,05)$.

Отримані дані, підтверджують необхідність проведення в першу чергу цілеспрямованих організаційних та медикоорганізаційних заходів направлених на первинну профілактику захворювань та формування ЗСЖ у військовослужбовців ВМС ЗС України, а саме:

3 метою популяризації військової служби, підвищення рівня авторитету та конкурентоспроможності $3 \mathrm{C}$ України, підвищення рівня задоволеності військовослужбовців необхідно врегулювати питання забезпеченості службовим та постійним житлом;

забезпечити неухильне виконання пп. 199-203 Закону України «Про Статут внутрішньої служби ЗС України» (зі змінами), де визначено, що робочий тиждень п'ятиденний з двома вихідними днями;

зобов'язати неухильне виконання військовослужбовцями плану бойової підготовки, а саме щоденні обов'язкові заняття з фізичної підготовки в робочий час. При цьому, забезпечити матеріальною базою (зали, площадки, тренажери, душі тощо) та вільний доступ до них; надати можливість військовослужбовцям вільно обирати час та варіант проведення заняття (гра, заняття на тренажерах тощо);

розглянути можливість забезпечення повноцінного та різноманітного харчування 
особового складу (офіцерського складу включно) в обід;

запровадити проведення 3 особовим складом індивідуальних бесід та групових психологічних тренінгів разом із психологами частини (у разі потреби 3 залученням медичних психологів);

для підвищення рівня пропаганди ЗСЖ спільно 3 командуванням та психологами частин розробити цикл лекцій щодо формування та виконання вимог ЗСЖ, вплив шкідливих звичок на стан здоров'я, на виникнення захворювань та ускладнення вже існуючих. Лекції повинні бути короткі (10-15 хв), гарно ілюстровані, матеріал викладений в простій та доступній формі;

запровадити, як обов'язковий метод, 1 раз на квартал вимірювання індексу маси тіла у особового складу, особливо офіцерів.

\section{Висновки}

1. Встановлено, військовослужбовців ВMC $3 \mathrm{C}$ України типовими чинниками, що знижують рівень ЗСЖ, $є$ порушення режиму харчування, режиму праці та відпочинку, високий рівень шкідливих звичок та недостатній рівень фізичної активності.

2. Виявлено, що 3 метою покращення підтримки ЗСЖ за даними соціологічного опитування впровадження матеріального

\section{Література}

1. Про схвалення Концепції Загальнодержавної програми «Здоров'я 2020: український вимір»: Розпорядження Кабінету Міністрів України від 31.10.2011 p. №1164-p. https://zakon.rada.gov.ua/laws/show/1164-2011p\#Text.

2. Загальна теорія здоров'я та здоров'язбереження: колективна монографія / заг. ред. проф. Ю. Д. Бойчук. Харків: Вид. Рожко С. Г., 2017. 488 с. http://hnpu.edu.ua/sites/default/files/files/Kaf zdor ta ko rr os/Zagalna teorija zdorovia i zdorviazberegennja.pdf.

3. Розвиток мотивації до здорового способу життя: Інформаційно-методичний посібник для офіцерів та сержантів / укладачі: Бойко О. В., Литвиненко Е. С., Страшко С. В. - Київ : Програма розвитку ООН, 2009.166 с. http://enpuir.npu.edu.ua/bitstream/123456789/16846/1/ Мотив ЗСЖ 2009\%20\%281\%29.pdf.

4. Соціальна медицина і організація охорони здоров'я / за ред. В. Ф. Москаленко. Київ : КнигаПЛЮС, 2010. 328 с.

5. Мороз Г. З., Бібік Т. А., Ткачук І. М. Оцінка медико-соціальних аспектів виконання вимог здорового способу життя військовослужбовцями Київського гарнізону. Проблеми військової охорони здоров'я. Зб. наук. пр. УВМА. К., 2009. Вип. 25. C. 90-98. заохочення для військовослужбовців превалює над використанням адміністративних заходів.

3. Більшість респондентів 1-ої та 2-ої групи недооцінюють вплив на стан здоров'я способу життя $(43,2 \%$ та $46,5 \%$, при р $>0,05)$ та екології $(6,8 \%$ та $7,0 \%$, при $р>0,05)$, перебільшуючи роль спадкових факторів $(31,8 \%$ та $30,2 \%$, при $p>0,05)$ та медичного обслуговування $(18,2 \%$ та $16,30 \%$, при $\mathrm{p}<0,05)$.

4. Встановлено, у військовослужбовців 3 ХСК та хронічною патологією, високу обізнаність щодо вимог ЗСЖ та низьке виконання даних вимог $(\mathrm{p}>0,05)$, низький рівень мотивації $(\mathrm{p}<0,05)$, не дотримання режиму харчування $(\mathrm{p}<0,05)$, нераціональне та незбалансоване харчування (p>0,05), низька фізична активність $(\mathrm{p}<0,01)$, недотримання режиму праці та відпочинку ( $<0,01)$, схильність до довготривалого переживання негативних емоцій $(\mathrm{p}<0,001)$, високий рівень психоемоційного навантаження на робочому місці ( $\mathrm{p}<0,01$ та $\mathrm{p}<0,05$ відповідно), високу розповсюдженість шкідливих звичок (куріння $(\mathrm{p}<0,01)$ та вживання алкоголю $(\mathrm{p}>0,05)) \mathrm{i}$ таких факторів ризику, як надмірна вага $(\mathrm{p}<0,05)$ у військовослужбовців 3 хронічною патологією та ожиріння $(\mathrm{p}<0,001)$ у військовослужбовців з ХСК, що збільшує ризик ускладнень у цих осіб.

6. Grossmeier J. The Art of Health Promotion: linking research to practice. American journal of health promotion : AJHP. 2018. 32(8). P. 1814. https://doi.org/10.1177/0890117118804149

7. American Psychiatric Association. DSM-5 Fact Sheets: Somatic Symptom Disorder. https://wwwpsychiatry-

org.translate.goog/psychiatrists/practice/dsm/educat ional-resources/dsm-5-fact-

sheets? $\times$ tr sl=en\& $\times$ tr $t l=u k \& \times$ tr $h l=u k \& \times$ tr pto =ajax,se,op,elem,sc

8. Ben-Zeev D, Corrigan PW, Britt TW, Langford L. Stigma of mental illness and service use in the military. Journal of Mental Health. 2012;21(3):264273. https://doi: 10.3109/09638237.2011.621468

9. Navy and Marine Corps Public Health Center. Fleet and Marine Corps Health Risk Assessment Annual Report, 2012. Washington, DC: Department of the Navy; 2013. https://www.med.navy.mil/sites/nmcphc/healthpromotion/Pages

10. Середа І.К., Олещенко 3.М. Комплексна оцінка медико-соціальних детермінант здорового способу життя військовослужбовців ВійськовоМорських Сил Збройних Сил України. Український військово-медичний журнал ,2021. Том 2. №1. 5260. https://doi.org/10.46847/ujmm.2021.1(2)-052 


\section{References}

1. On approval of the Concept of the National Program «Health 2020: Ukrainian Dimension» (2011). Order of the Cabinet of Ministers of Ukraine dated 31.10.2011

№1164-r. https://zakon.rada.gov.ua/laws/show/1164-2011p\#Text

2. General Theory of Health and Healthcare: a collective monograph. (2017). According to the general editing by prof. Boychuk, Yu. D. Kharkiv: Rozhko SG, 488.

http://hnpu.edu.ua/sites/default/files/files/Kaf zdor ta korr os/Zagalna teorija zdorovia i zdorviazberege nnja.pdf.

3. Boyko, O.V., Litvinenko, E.S., Strashko, S.V. (2009). Development of motivation for a healthy lifestyle: Information and methodical manual for officers and sergeants. Kyiv: UN Development Program, 166. http://enpuir.npu.edu.ua/bitstream/123456789/168 46/1/Мотив ЗСЖ 2009\%20\%281\%29.pdf

4. Social medicine and health care organization (2010). Ed. by prof. Moskalenko V.F. Kyiv: Book-PLUS, 328.

5. Moroz, G.Z., Bibik, T.A., Tkachuk, I.M. (2009). Evaluation of medical and social aspects of compliance with the requirements of a healthy lifestyle by servicemen of the Kiev garrison. Problems of military health care: Collection of scientific works of the Ukrainian military medical academy, (25), 90-98.
6. Grossmeier J. (2018). The Art of Health Promotion: linking research to practice. American journal of health promotion : AJHP, 32(8), 1814. https://doi.org/10.1177/0890117118804149

7. American Psychiatric Association. DSM-5 Fact Sheets: Somatic Symptom Disorder. https://wwwpsychiatry-

org.translate.goog/psychiatrists/practice/dsm/educat ional-resources/dsm-5-fact-

sheets? $\times$ tr sl=en\& $\times$ tr tl=uk\& $\times$ tr hl=uk\& $\times$ tr pto $=$ ajax,se,op,elem, sc

8. Ben-Zeev D, Corrigan PW, Britt TW, Langford L. (2012). Stigma of mental illness and service use in the military. Journal of Mental Health, 21(3), 264273. https://doi: 10.3109/09638237.2011.621468

9. Navy and Marine Corps Public Health Center. Fleet and Marine Corps Health Risk Assessment Annual Report, 2012. Washington, DC: Department of the Navy; 2013.

https://www.med.navy.mil/sites/nmcphc/healthpromotion/Pages

10. Sereda I.K., Oleshchenko Zh.M. (2021). Comprehensive assessment of medical and social determinants of healthy lifestyle among servicemen of the Naval Forces of the Armed Forces of Ukraine. Ukrainian Journal of Military Medicine $\quad, \quad 2 \quad(1), \quad 52$ 60. https://doi.org/10.46847/ujmm.2021.1(2)-052

\title{
КОМПЛЕКСНАЯ ОЦЕНКА ОСНОВНЫХ СОСТАВЛЯЮЩИХ ЗДОРОВОГО ОБРАЗА ЖИЗНИ У ВОЕННОСЛУЖАЩИХ ВОЕННО-МОРСКИХ СИЛ ВООРУЖЕННЫХ СИЛ УКРАИНЫ С БОЛЕЗНЯМИ СИСТЕМЫ КРОВООБРАЩЕНИЯ И ХРОНИЧЕСКОЙ ТЕРАПЕВТИЧЕСКОЙ ПАТОЛОГИЕЙ
}

\author{
И.к. Среда' ${ }^{1}$ Ж.М. Олещенко ${ }^{2}$ \\ 1 Украинская военно-медицинская академия, г. Киев, Украина \\ ${ }^{2}$ Командование Морской пехоты Военно-Морских Сил ВС Украины, г. Николаев, Украина
}

\begin{abstract}
Цель работы - комплексно оценить медико-социальные аспекты основных составляющих здорового образа жизни у военнослужащих ВMC ВC Украины с болезнями системы кровообращения и хронической терапевтической патологией для выявления наиболее значимых рисков и разработки на этой основе сфокусированных мероприятий по их уменьшению.

Материалы и методы. Медико-социальные аспекты основных составляющих здорового образа жизни (ЗОЖ) у военнослужащих ВMC ВC Украины были проанализированы по результатам социологического опроса с применением спещиально разработанной анкеты. Анкета включала 43 вопроса, возведенных в информационные блоки: общие сведения, осведомленность о здоровом образе жизни, распространенность и причины вредных привычек, анализ образа жизни (особенностей питания, физической активности, режима труда и отдыха), самооценка состояния здоровья и таблицу по определению удовлетворенности разными сторонами жизни следующими критериями: условия труда и перспективы служебного роста, обеспеченность жильем и бытовые условия, семейное и материальное благополучие, досуг и медицинское обслуживание, социальная и правовая защита.иМетодом случайной выборки было проведено анкетный опрос 128 военнослужащих ВМС ВС Украины, проходивших углубленное медицинское обследование в 2019 году. В исследуемую группу вошли лица мужского пола, средний возраст -

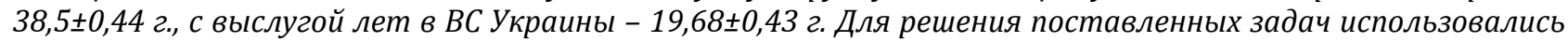
следующие методы: медико-социологический, медико-статистический, системный подход.
\end{abstract}

Результаты. В статье проведена комплексная оценка медико-социальных аспектов основных составляющих ЗОЖ у военнослужащих ВMC BC Украины с болезнями системы кровообращения $и$ хронической терапевтической патологией по результатам социологического опроса с применением специально разработанной анкеты. Комплексный анализ результатов опроса позволил выделить

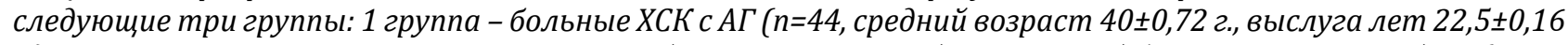
2.); 2 группа - военнослужащие с хронической терапевтической патологией без сопутствующей $А \Gamma(n=43$,

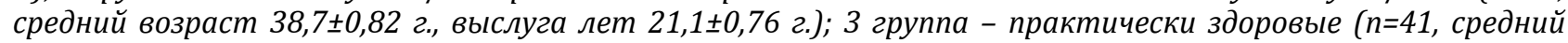

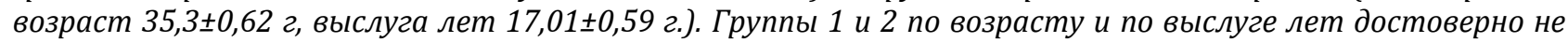
отличались от группы практически здоровых (p>0,05). Выявлено достаточно высокую осведомленность 
военнослужащих трех групп по 30Ж (86,4\% 88,4\% и 95,1\% при р>0,05). Среди причин, препятствующих внедрению ЗОЖ, респонденты всех групп определили привычки и материальные трудности. Обращает на себя внимание низкий уровень мотивации 1-й и 2-й группы, что 3,2 и 2,3 раза (6,8\% и 9,3\% соответственно) достоверно ниже $(p<0,05)$ по сравнению с уровнем мотивации у 3-й группы $(22,0 \%)$. Довольно единодушно респонденты считают необходимость внедрения материального поощрения (81,8\%, 79,1\% и 70,1\% соответственно, при р>0,05) для военнослужащих, не имеющих вредных привычек и поддерживающих высокий уровень здоровья. Среди респондентов 1-й и 2-й группы установлена достоверно высокая распространенность курения (56,8\% и 58,1\% против 34,1\% соответственно при р<0,01). Они меньше соблюдают режим питания (34,1\% и 37,2\% против 51,2\%, при p<0,05) и имеют недостаточную физическую активность (61,4\%, 65,1\% против 82,9\%, при р<0,01). Нормальный сон продолжительностью 7-8 часов отмечали только 11,4\% респондентов 1-й, 13,9\% -2-й и 21,9\% - 3-й групп (р>0,05). Большинство респондентов характеризовали уровень психоэмоциональной нагрузки на рабочем месте, как высокий (63,2\% респондентов 1-й группы p<0,01, 55,8\% - 2-й группы p<0,05 против 39,0\% 3-й группы). Большинство респондентов трех групп имеют общие проблемы в условиях жизни, а именно: необеспеченность жильем, неудовлетворительные бытовые условия, низкий уровень материального благополучия и недостаточный уровень социальной и правовой защиты. Полученные данные подтверждают необходимость проведения в первую очередь целенаправленных организационных и медико-организационных мероприятий, направленных на первичную профилактику заболеваний и формирование зОЖ у военнослужащих ВМС ВС Украины.

Выводы. Установлено, что для военнослужащих ВМС ВС Украины типичными факторами, снижающими уровень ЗОЖ, является нарушение режима питания, труда и отдыха, высокий уровень вредных привычек и недостаточный уровень физической активности. Выявлено, что с целью улучшения поддержания ЗОЖ по данным социологического опроса, внедрение материального поощрения для военнослужащих превалирует над использованием административных мер. Большинство респондентов 1й и 2-й группы недооценивалт влияние на состояние здоровья образа жизни (43,2\% и 46,5\%, при p>0,05) и экологии (6,8\% и 7,0\%, при р>0,05), преувеличивая роль наследственных факторов (31,8\% и 30,2\%, при $p>0,05)$ и медищинского обслуживания (18,2\% и 16,30\%, при p<0,05). Установлено, у военнослужащих с ХСК и хронической патологией, высокую осведомленность о требованиях ЗОЖ и низкое выполнение данных требований (p>0,05), низкий уровень мотивации $(p<0,05)$, не соблюдение режима питания ( $p<0$, 05), нерациональное и несбалансированное питание $(p>0,05)$, низкая физическая активность ( $p<0,01)$, несоблюдение режима труда и отдыха $(p<0,01)$, склонность к длительному переживанию негативных эмоций $(p<0,001)$, высокий уровень психоэмоциональной нагрузки на рабочем месте $(p<0,01$ u $p<0,05$ соответственно), высокая распространенность вредных привычек (курение (p<0,01) и употребление алкоголя $(p>0,05))$ и таких факторов риска как избыточный вес $(p<0,05)$ у военнослужащих с хронической патологией и ожирение ( $<<0,001)$ у военнослужащих с ХСК, что увеличивает риск осложнений у этих лиц.

Ключевые слова: военнослужащие Военно-Морских Сил ВС Украины, здоровый образ жизни, факторы риска.

\title{
COMPREHENSIVE ASSESSMENT OF THE HEALTHY LIFESTYLE BASIC COMPONENTS AMONG NAVY SERVICEMEN OF THE ARMED FORCES OF UKRAINE WITH CARDIOVASCULAR DISEASES AND CHRONIC THERAPEUTIC PATHOLOGY
}

\author{
I.K. Sereda ${ }^{1}$, Zh.M. Oleshchenko ${ }^{2}$
}

\author{
1 Ukrainian Military Medical Academy, Kyiv, Ukraine \\ ${ }^{2}$ Marine Command of the Naval Forces of the Armed Forces of Ukraine, Mykolaiv, Ukraine
}

The purpose is to comprehensively assess the medical and social aspects of the main components of a healthy lifestyle in the Navy servicemen of the Armed Forces of Ukraine with cardiovascular diseases and chronic therapeutic pathology to identify the most important risks and develop on this basis focused measures to reduce them.

Materials and methods. Medical and social aspects of the main components of a healthy lifestyle among Navy servicemen of the e Armed Forces of Ukraine have been analyzed based on the results of a sociological survey using a specially developed questionnaire. The questionnaire included 43 requests, which were summarized in some information blocks: general information, awareness of a healthy lifestyle, prevalence and causes of bad habits, analysis of lifestyle (diet, physical activity, work and rest), self-assessment of health and a table for determining satisfaction with different aspects of life by the following criteria: working conditions and career prospects, housing and living conditions, family and material well-being, leisure and medical care, social and legal protection, etc. A questionnaire was used to conduct a questionnaire survey of 128 servicemen of the Navy servicemen who underwent an in-depth medical examination in 2019. The study group included males, average age - $38.5 \pm 0.44$, with $19.68 \pm$ 0.43 years of service in the Armed Forces of Ukraine. Methods were used: medical and sociological, medical-statistical, system analysis.

Results. The article considers the medical and social aspects of the main components of a healthy lifestyle among Navy servicemen of the Armed Forces of Ukraine based on the results of a poll using a specially designed questionnaire. A comprehensive analysis of the survey results made it possible to distinguish the following three groups: Group 1 - patients with HSC with AH ( $n=44$, average age $40 \pm 0.72$ years, length of service $22.5 \pm 0.16$ years); 
Group 2 - servicemen with chronic therapeutic pathology without concomitant hypertension ( $n=43$, average age 38.7 \pm 0.82 , length of service $21.1 \pm 0.76)$; Group 3 - practically healthy $(n=41$, average age $35.3 \pm 0.62 \mathrm{~g}$, length of service $17.01 \pm 0.59$ years). Groups 1 and 2 in terms of age and length of service did not significantly differ from the group of practically healthy people ( $p>0.05)$. A fairly high awareness of the servicemen of the three groups on healthy lifestyles was revealed (86.4\% $88.4 \%$ and $95.1 \%$ with $p>0.05)$. Among the reasons that impeded the introduction of healthy lifestyle, the respondents of all groups identified habits and material difficulties. Noteworthy was the low level of motivation of the 1st and 2nd groups, which was 3.2 and 2.3 times (6.8\% and $9.3 \%$, respectively) significantly lower $(p<0.05)$ compared to the level motivation in the 3rd group (22.0\%). The respondents quite unanimously consider the need to introduce material incentives (81.8\%, 79.1\% and $70.1 \%$, respectively, with $p>0.05)$ for servicemen who did not have bad habits and maintain a high level of health. Among the respondents of the 1st and 2nd groups, a significantly high prevalence of smoking was established (56.8\% and 58.1\% versus 34.1\%, respectively, at $p<0.01$ ). They follow the diet less (34.1\% and $37.2 \%$ versus $51.2 \%$, with $p<0.05)$ and had insufficient physical activity (61.4\%, $65.1 \%$ versus $82.9 \%$, with $p<0.01$ ). Normal sleep lasting $7-8$ hours was noted only by $11.4 \%$ of respondents in the 1 st group, $13.9 \%$ in the 2 nd and $21.9 \%$ in the 3rd groups ( $p>0.05)$. The majority of respondents characterized the level of psychoemotional load at the workplace as high (63.2\% of respondents in the 1st group $p<0.01,55.8 \%$ in the 2 nd group $p<0.05$ versus $39.0 \%$ of the $3 r$ groups). Most of the respondents in the three groups had common problems in living conditions, namely: lack of housing, unsatisfactory living conditions, low level of material well-being and insufficient level of social and legal protection. The obtained data confirmed the need to carry out, first of all, purposeful organizational and medical-organizational measures aimed at the primary prevention of diseases and the formation of healthy lifestyles among the servicemen of the Navy of the Armed Forces of Ukraine.

Conclusions. It was found that for the servicemen of the Navy of the Armed Forces of Ukraine, the typical factors that reduce the level of a healthy lifestyle were a violation of the diet, work and rest, a high level of bad habits and an insufficient level of physical activity. It was revealed that in order to improve the maintenance of a healthy lifestyle, according to a sociological survey, the introduction of material incentives for military personnel prevails over the use of administrative measures. The majority of respondents in the 1st and 2 nd groups underestimated the impact on health of lifestyle (43.2\% and 46.5\%, with $p>0.05)$ and ecology (6.8\% and $7.0 \%$, with $p>0.05)$, exaggerating the role of hereditary factors (31.8\% and $30.2 \%$, with $p>0.05)$ and medical services $(18.2 \%$ and $16.30 \%$, with $p<0.05)$. It was found that in servicemen with HSC and chronic pathology, high awareness of the requirements of healthy lifestyle and low compliance with these requirements $(p>0.05)$, low level of motivation $(p<0.05)$, non-compliance with diet $(p<0.05)$, irrational and unbalanced nutrition $(p>0.05)$, low physical activity $(p<0.01)$, non-compliance with the work and rest regimen $(p<0.01)$, a tendency to long-term experience of negative emotions $(<0.001)$, a high level of psychoemotional load at the workplace ( $p<0.01$ and $p<0.05$, respectively), a high prevalence of bad habits (smoking $(p<0.01)$ and alcohol consumption $(p>0.05))$ and such risk factors as overweight $(p<0.05)$ in military personnel with chronic pathology and obesity $(p<0.001)$ in military personnel with HSC, which increases the risk of complications in these individuals.

Key words: servicemen of the Naval Forces of the Armed Forces of Ukraine, healthy lifestyle, risk factors.

Конфлікт інтересів: відсутній.

Conflicts of interest: authors have no conflict of interest to declare.

\section{Відомості про авторів:}

Середа I.К. A,B,C,D,E,F - підполковник медичної служби, к.мед.н., доцент, доцент кафедри організації медичного забезпечення збройних сил Української військово-медичної академії, м. Київ.

Олещенко Ж.М. B,C,D - підполковник медичної служби, начальник медичної служби Морської Піхоти Військово-Морських Сил Збройних Сил України, м. Миколаїв.

$A$ - концепція та дизайн дослідження; $B$ - збір даних; $C$ - аналіз та інтерпретація даних;

$D$ - написання статmi; $E$ - редагування статmi; $F$ - остаточне затвердження статті.

Сведения об авторах:

Середа И.К. - подполковник медицинской службы, к.мед.н., доцент, доцент кафедры организации медицинского обеспечения вооруженных сил Украинской военно-медицинской академии, г. Киев.

Олещенко Ж.Н. - подполковник медицинской службы, начальник медицинской службы Морской Пехоты Военно-Морских Сил Вооруженных Сил Украины, м. Николаев.

\section{Information about authors:}

Sereda I.K. A,B,C,D,E,F - LtC MS, PhD, Associate Professor, associate professor of the Department of Armed Forces Medical Support of the Ukrainian Military Medical Academy, Kyiv, Ukraine. E-mail irensereda@ukr.net, https://orcid.org/0000-0003-4013-6941.

Oleshchenko Zh.M. B, C, D - LtC MS, Chief of the Medical Service of Marine Command of the Naval Forces of the Armed Forces of Ukraine, Mykolaiv, Ukraine.

$A$ - research concept and design; $B$ - collection and/or assembly of data; $C$-data analysis and interpretation;

$D$ - writing the article; $E$ - critical revision of the article; $F$ - final approval of the article.

Адреса для листування: вул. Московська, 45/1, буд. 33, м. Київ 01015

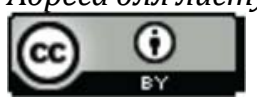

